\title{
International Experience in Managing Intellectual Capital of Territories for Innovative Development
}

\author{
Kuzminykh Natalia \\ Department of innovative Economics, Institute of \\ Economics Finance and business \\ Bashkir State University \\ Ufa, Russia \\ kashatan@inbox.ru
}

\author{
Mashkina Dinara \\ Department of innovative Economics, Institute of \\ Economics Finance and business \\ Bashkir State University \\ Ufa, Russia \\ khakimova.dinara@mail.ru
}

\author{
Roze Nelly \\ Department of innovative Economics, Institute of Economics Finance and business \\ Bashkir State University \\ Ufa, Russia \\ nellliona@yandex.ru
}

\begin{abstract}
Actuality. Today the role of intellectual capital, which integrates in its structure a significant part of intellectual assets and constitutes a basis of innovative development of the country, is consolidated at the legislative level and acquires formalized features of the priority direction of state activity. The transition to an innovative economy, which is characterized by high speed of socio-economic development, formation of intellectual capital as a market and increase of its role, forces countries to develop strategies for innovative development.

Methods. Using the summary of the conceptual framework review and the existing approaches to the formation and development of intellectual capital market used methods of abstraction, logical analysis and synthesis, we obtained a complete picture that describes conditions and factors of the intellectual capital market formation. Methods of evolutionaryhistorical approach provided identification of cause-and-effect relations and establishment of key regularities describing transformation of the market of intellectual capital. In order to concretize trends and identify promising areas of intellectual capital market development for the purposes of innovative development strategy choice, the methods of formalized representation of control systems, combinatorial and situational modeling are applied.
\end{abstract}

Results. The essence of intellectual capital is revealed, intellectual capital market term is more closely defined, its subjects and structural elements are presented.

The obtained results made it possible to develop a classification of innovative development strategies. This classification allows to expand the theoretical basis for studying the features of innovative development of various countries with practice-oriented knowledge to simplify and boost efficiency in exchange of experience among the professional scientific community.
Provided this, the matrix of a choice of a strategy of innovative development at the country level is developed with regard to comparison of the offered classification and type of the market of intellectual capital. This tool is based on the identification of the optimal combination of the national innovation system model and level of influence of intellectual capital on the development of the country's innovation system.

The scientific novelty of this study contributes to development of a matrix of formation and implementation of the innovative development of the country's strategy model based on the characteristics of the intellectual capital market operating in this country.

Keywords: innovation economics, innovative development, strategy, intellectual capital, intellectual capital market, national innovation system

\section{INTRODUCTION}

Innovative way of development is chosen by the leading countries as a priority. Meanwhile, the intellectual component of innovative processes evolves at a higher rate and provides superiority in the competitiveness. Innovative development is a systemic process of socio-economic development based on knowledge and innovation, which allows to implement competitive advantages of the country's economy, secure sustainable economic growth, improve quality and population's standard of living through harmonization of participants interests in the informational space. Transition to an innovative economy causes significant change in the quality standards of human resources, intellectualization of labor process and economic relations. In this regard, the key 
functioning complexity of the socio-economic system which include large number of functional and procedural relationships.

\section{LITERATURE REVIEW}

Comprehension of intangible assets impacted on the change in value of companies which in turn caused formalization and specification of new categories and actualization of existing conceptual apparatus in line with current processes. It caused origin of the term "intellectual capital", followed by first scientific and then practical usage in the 60 s of the 20th century.

There are many author's interpretations of "intellectual capital" concept, but number of approaches distinguish definition by following methodological principles:

- Similar as a balance sheet value. Intellectual capital is regarded as an intangible asset that can be measured within existing accounting and valuation system, resulting in addition company value (E. Brooking, A. Gaponenko, L. Prusak, O. Novoseltsev, A. Pulik, et all.).

- Measured as a resource. Intellectual capital is considered as an intangible resource and a source of competitive advantage (E. Jamay, G. Chernoles, T. Fortune et al.).

- Systematic. Intellectual capital is considered as a set or sum of knowledge, abilities, skills of employees and intangible elements of corporate and management culture coexisting in the organization (T. Stewart, J. Roos, L. Edvinsson, D. Zeghal, A. Maaloul, et all).

Review of theoretical assumptions indicates that most researchers tend to interpret corporate intellectual capital as a set of knowledge, skills and abilities of employees and intangible assets that create added value and increase the welfare of stakeholders.

Focus of scientific interest in region's or country's intellectual capital research lies in measurement of affection on strategic management influence and its impact on wellbeing and wealth of the nation. The most impactful papers which formed concept of intellectual capital at the national level are N. Bontis, José Martí Maria Viedma, D. Andriessen, S. Stem, Th. Malhotra, A. Rimbaud, E. Pashera, D. Wasiak. By reference to research of the above-mentioned authors, it is possible to formulate the following distinctive characteristics of the national intellectual capital:

- Absence of single universally recognized concept definition, common approach to identification of intellectual capital structural components on national scale, as well as their measurement.

- The core concepts commonly based upon resource approach, where intellectual capital acts as a resource for the formation of national wealth and competitiveness of the country.

- Expanded structure in comparison with intellectual capital at the enterprise level, which is explained by
- Applicability of corporate-level methodologies to national intellectual capital measurment, which are usually based on the calculation of integral indicators.

- Geographical linkage of national capital to a specific territory, which determines the heterogeneity and limitation of its movement [1].

"Intellectual capital" as an economic phenomenon have distinguishing cornerstone features. The essence of intellectual capital consists from the system of operations forming it. intellectual capital is formed not by addition of its individual parts, but as a property of their interaction. This condition emphasizes importance of structural composition of intellectual capital and the importance of each of its parts. Scientific community have following consensus: division of intellectual capital into three parts such as human capital, relational capital and structural capital. Such method applicable to both corporate and regional and national levels. Based on the analysis of scientific papers of authors who studied this aspect of the theory of intellectual capital (see table I), we will define the introduced concepts [2]. 
of elements of the system, for example: the quality level of education, healthcare, social security.

Structural capital is a part of intellectual capital related to the administrative and organizational-managerial component in the aggregate (procedures, technologies, management systems, technical and software, administrative structure) and contributes to the codification of knowledge.

Relationship capital, being a part of intellectual capital, reflects the possibility of building mutually beneficial relations with external and internal counterparties, which affect socioeconomic, trade and economic relations, political relations, organizational and psychological relations that are built within the socio-economic systems.

Thus, intellectual capital is a complex heterogeneous phenomenon, which can be defined as an intangible resource of innovative development, formed and reproduced as a result of interaction of human, structural, relational capital, which forms basis of competitiveness and well-being of the territory in the transition to an innovative economy. Interaction of the intellectual capital elements is the basis of its reproduction. The human capital reflects quality of knowledge transmitters, structural capital reflects level of knowledge codification, and relational capital reflects opportunities for exchange of codified knowledge through their transmitters.

These processes at the corporate and national level take place in the ecosystem, which can be defined as the intellectual capital market.

Intellectual capital term considered to include totality of economic relations arising in the process of transformation of intellectual capital in the market.

It consists from the creators of intellectual capital, which form the supply, and consumers of intellectual capital, which form the demand for it and its consumption. The object of purchase and sale in the market are knowledge, abilities, skills, inventions, innovative products, etc. The framework of the intellectual capital market consists from state, investment and infrastructure support and markets of expertise, intellectual property and innovation [19].

\section{RESULTS}

At present, the role of intellectual capital, which integrates a significant part of intellectual assets in its structure and the basis of innovative development of the country, is in active phase of legislative institutionalization and acquires formalized signs of the pivotal direction of state activity.

The key points, concretizing principles and recommendations for required for development of mechanism aimed toward effective functioning of intellectual capital of the region can be found in system-forming documents of the strategically-aimed nature. They include revealing the longterm and short-term plans and activities for creating environment and infrastructure to ensure the region's competitiveness in the context of sustainable innovative development [20].
Human capital is a part of intellectual capital, which includes human resources and reserves, as well as formation 
Currently many regions and countries have approved system and policy documents containing national strategies of innovative development. For instance, programs of scientific, technical and technological development, concepts of intangible resources` management, in particular human capital and intangible infrastructure. To illustrate, in last three years (since 2017), more than 25 countries have presented national strategies for the development of artificial intelligence, which opens up new prospects for the formation and use of intellectual capital, since the use of AI completely changes the value chain.

On the basis of countries' program and development strategies analysis, which has set goal of transition to innovative model of economic development, classification of countries' strategies has been proposed, in relation to the type of influence on innovative development [21]. This classification allows to extend the theoretical basis of studying the characteristics of innovation development of the countries by bringing practice-oriented knowledge to simplify and improve the efficiency of the process of exchange of experience in the professional scientific community (table II).

TABLE II. CLASSIFICATION OF INNOVATION DEVELOPMENT STRATEGIES

\begin{tabular}{|c|c|c|c|}
\hline \multirow[t]{2}{*}{ Parameters } & \multicolumn{3}{|c|}{$\begin{array}{c}\text { Influence of intellectual capital on innovative } \\
\text { development through }\end{array}$} \\
\hline & $\begin{array}{c}\text { The carriers } \\
\text { quality (human } \\
\text { capital) }\end{array}$ & $\begin{array}{c}\text { The level of } \\
\text { codification } \\
\text { (structural } \\
\text { capital) }\end{array}$ & $\begin{array}{c}\text { The exchange } \\
\text { process } \\
\text { (relationship capital) }\end{array}$ \\
\hline $\begin{array}{l}\text { Management } \\
\text { focus }\end{array}$ & Personnel & $\begin{array}{l}\text { Science and } \\
\text { technology }\end{array}$ & $\begin{array}{l}\text { Relations regulation } \\
\text { system }\end{array}$ \\
\hline Main activity & $\begin{array}{l}\text { Development } \\
\text { of skills, } \\
\text { competences of } \\
\text { personnel } \\
\text { resources, } \\
\text { creation of } \\
\text { conditions for } \\
\text { cultivation of } \\
\text { unique highly } \\
\text { qualified } \\
\text { personnel }\end{array}$ & $\begin{array}{l}\text { Fundamental } \\
\text { research, } \\
\text { development } \\
\text { of high-tech } \\
\text { products and } \\
\text { services }\end{array}$ & $\begin{array}{l}\text { Attraction of highly } \\
\text { qualified personnel } \\
\text { of the international } \\
\text { level, development } \\
\text { of mechanisms of } \\
\text { social and economic } \\
\text { partnership and } \\
\text { cooperation }\end{array}$ \\
\hline $\begin{array}{c}\text { Areas and areas } \\
\text { where significant } \\
\text { changes are } \\
\text { planned }\end{array}$ & $\begin{array}{l}\text { Medicine, } \\
\text { education, } \\
\text { security, small } \\
\text { business }\end{array}$ & $\begin{array}{l}\text { Finance, } \\
\text { global } \\
\text { databases, } \\
\text { digital } \\
\text { infrastructure } \\
\text { cybersecurity }\end{array}$ & $\begin{array}{l}\text { Socially important } \\
\text { areas and spheres, } \\
\text { urbanistic, national } \\
\text { security, mobility, } \\
\text { legislation }\end{array}$ \\
\hline $\begin{array}{l}\text { The sources and } \\
\text { agents of change }\end{array}$ & $\begin{array}{l}\text { Small business, } \\
\text { startups, } \\
\text { professionals }\end{array}$ & $\begin{array}{l}\text { Scientists, } \\
\text { researchers, } \\
\text { innovation } \\
\text { clusters }\end{array}$ & $\begin{array}{l}\text { State institutions } \\
\text { and specialized civil } \\
\text { services }\end{array}$ \\
\hline Examples & $\begin{array}{l}\text { South Korea } \\
\text { "Artificial } \\
\text { intelligence } \\
\text { research and } \\
\text { development } \\
\text { strategy in } \\
\text { South Korea", } \\
2018 \\
\text { Sweden } \\
\text { "Nationell } \\
\text { inriktning för } \\
\text { artificiell } \\
\end{array}$ & $\begin{array}{l}\text { Singapore } \\
\text { Program AI } \\
\text { Singapore, } \\
2017 \\
\text { Russia } \\
\text { "National } \\
\text { strategy for } \\
\text { the } \\
\text { development } \\
\text { of artificial } \\
\text { intelligence } \\
\text { for the period }\end{array}$ & $\begin{array}{l}\text { Japan "Artificial } \\
\text { Intelligence } \\
\text { Technology } \\
\text { Strategy", } 2017 \\
\text { Taiwan "The } \\
\text { actions of Taiwan in } \\
\text { the field of artificial } \\
\text { intelligence", } 2018 \\
\text { New Zealand } \\
\text { "Artificial } \\
\text { intelligence: } \\
\text { shaping the future }\end{array}$ \\
\hline
\end{tabular}

\begin{tabular}{|c|c|c|c|}
\hline & $\begin{array}{l}\text { intelligens", } \\
2018 \\
\text { Canada «Pan- } \\
\text { Canadian } \\
\text { Artificial } \\
\text { Intelligence } \\
\text { Strategy», } \\
2017 \\
\text { Australia } \\
\text { «Australia } \\
2030: \\
\text { Prosperity } \\
\text { through } \\
\text { Innovation» } \\
\text { 2017 }\end{array}$ & $\begin{array}{l}\text { up to } 2030 " \text { ", } \\
\text { approved by } \\
\text { the decree of } \\
\text { the President } \\
\text { of the } \\
\text { Russian } \\
\text { Federation in } \\
\text { October } \\
\text { 2019, UAE } \\
\text { "UAE } \\
\text { Strategy for } \\
\text { Artificial } \\
\text { Intelligence", } \\
\text { 2017 } \\
\text { Mexico } \\
\text { "Towards an } \\
\text { AI strategy in } \\
\text { Mexico: } \\
\text { Harnessing } \\
\text { the } \\
\text { Revolution", } \\
\text { 2018 } \\
\text { China "A } \\
\text { Next } \\
\text { Generation } \\
\text { Artificial } \\
\text { Intelligence", } \\
\text { 2017 } \\
\text { India } \\
\text { Discussion } \\
\text { Paper } \\
\text { "National for } \\
\text { Strategy for } \\
\text { Artificial } \\
\text { Intelligence", } \\
\text { 2018 } \\
\text { Germany } \\
\text { "Germany } \\
\text { Federal } \\
\text { Government' } \\
\text { s Artificial } \\
\text { Intelligence } \\
\text { strategy" } \\
2018 \\
\end{array}$ & $\begin{array}{l}\text { of New Zealand", } \\
2018 \\
\text { Italy White paper } \\
\text { "Artificial } \\
\text { Intelligence at the } \\
\text { service of the } \\
\text { citizen", } 2018\end{array}$ \\
\hline Type of strategy & $\begin{array}{l}\text { Breakthrough } \\
\text { strategy, build- } \\
\text { up strategy, } \\
\text { defensive } \\
\text { strategy }\end{array}$ & $\begin{array}{l}\text { Exploratory } \\
\text { strategy, } \\
\text { patient } \\
\text { strategy, } \\
\text { violent } \\
\text { strategy }\end{array}$ & $\begin{array}{l}\text { Cooperative } \\
\text { interaction strategy, } \\
\text { diversification } \\
\text { strategy, integration } \\
\text { strategy }\end{array}$ \\
\hline
\end{tabular}

Also, depending on how effectively elements of intellectual capital market function and interact with each other, a particular type of market is configured. On these grounds, grouping classification of the intellectual capital market is proposed, based on following classification features: level of market development, level of market efficiency, territorial feature and the specific market model (figure 1) [22]. Based on the hierarchical structure of the intellectual capital market, it can be divided on a territorial basis on the following types: regional, country and world scale. It is also possible to distinguish the municipal scale type market of intellectual capital, but at this scale it is hardly possible to review it as fully formed market. The reason for this may be lack of various resources, absence of some structural elements of the market, etc. 
TABLE III. MATRIX OF INNOVATIVE DEVELOPMENT STRATEGY SELECTION AT THE COUNTRY LEVEL

Market of intellectual capital defined by stage of build-up can be categorized into emerging and developed market. Efficiency of market and its elements is next classification feature. Thus, intellectual capital market can be divided into a low-efficient, a medium-efficient, and an efficient type [23].

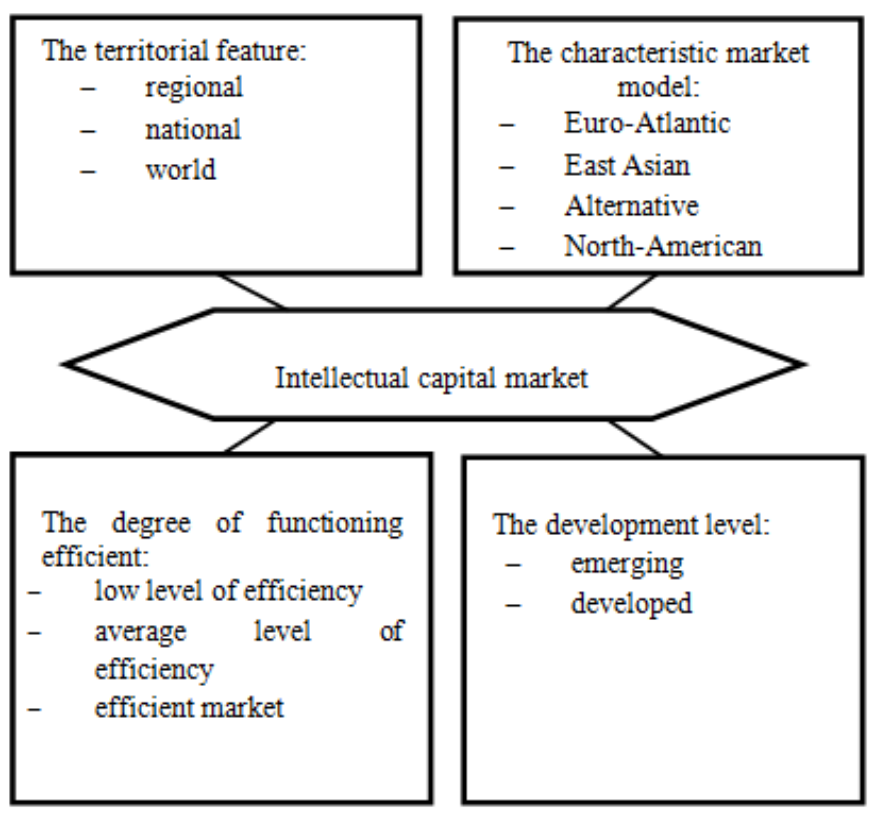

Fig. 1. Classification of intellectual capital market

National innovation system model determined by influence of state political structure, cultural characteristics and differences between countries, as well as many other factors, whereby caused change of model's properties, which itself is the basis of the intellectual capital market. Taking into account elements formation and functioning peculiarities of intellectual capital market in different countries, there are four main market models: Euro-Atlantic, East Asian, alternative and North American.

In summary, we can conclude that intellectual market capital functioning proceeds under influence of many factors, and the formation of a particular market type is greatly influenced by the interaction of market elements among themselves.

Thus, proposed classification is not fully comprehensive, and it, like any other, can be modified by addition of new classification features, or by enlarging or detailing existing features.

Considering the efficiency level of the intellectual capital market and the proposed classification, provided composed matrix for selection of innovative development strategy at the country level (table III).

\begin{tabular}{|c|c|c|c|}
\hline \multirow{3}{*}{$\begin{array}{l}\text { Classification of the } \\
\text { intellectual capital } \\
\text { market by the degree } \\
\text { of efficiency of } \\
\text { functioning }\end{array}$} & \multirow{2}{*}{\multicolumn{3}{|c|}{$\begin{array}{c}\text { Innovative development strategy based on } \\
\text { the use of intellectual capital } \\
\text { Influence of intellectual capital on } \\
\text { innovative development through }\end{array}$}} \\
\hline & & & \\
\hline & $\begin{array}{c}\text { The carriers } \\
\text { quality } \\
\text { (human } \\
\text { capital) }\end{array}$ & $\begin{array}{l}\text { The level of } \\
\text { codification } \\
\text { (structural } \\
\text { capital) }\end{array}$ & $\begin{array}{l}\text { Exchange } \\
\text { process } \\
\text { (relationship } \\
\text { capital) }\end{array}$ \\
\hline $\begin{array}{l}\text { The low level of } \\
\text { performance (alternative } \\
\text { model) }\end{array}$ & $\begin{array}{l}\text { Breakthrou } \\
\text { gh strategy }\end{array}$ & $\begin{array}{l}\text { Exploratory } \\
\text { strategy }\end{array}$ & $\begin{array}{l}\text { Cooperative } \\
\text { interaction } \\
\text { strategy, }\end{array}$ \\
\hline $\begin{array}{l}\text { The average level of } \\
\text { efficiency (the East } \\
\text { Asian model) }\end{array}$ & $\begin{array}{l}\text { Build-up } \\
\text { strategy }\end{array}$ & $\begin{array}{l}\text { Patient } \\
\text { strategy }\end{array}$ & $\begin{array}{l}\text { Diversification } \\
\text { strategy }\end{array}$ \\
\hline $\begin{array}{l}\text { The efficient market } \\
\text { (Euro-Atlantic r and } \\
\text { North American } \\
\text { models) }\end{array}$ & $\begin{array}{l}\text { Defensive } \\
\text { strategy }\end{array}$ & $\begin{array}{l}\text { Violent } \\
\text { strategy }\end{array}$ & $\begin{array}{l}\text { Integration } \\
\text { strategy }\end{array}$ \\
\hline
\end{tabular}

\section{CONCLUSION}

Complex analysis of international ratings, statistical data exploring the topic of countries innovative development, regulatory framework, etc. defined problems specific to the intellectual capital market.

Key factors include: lack of a legislative framework regulating the intellectual capital market, low level of infrastructure support of the market, lack of investment platform for the market.

Continuous common trend in the intellectual capital market is integration of the markets of different countries into a single scientific, technical and innovative space to ensure strengthening of scientific and innovative potential.

From these considerations, it is appropriate to create tools that allow to choose suitable strategy for innovative development, as well as to coordinate the strategies of different levels among themselves.

\section{REFERENCES}

[1] N.Sh. Roze, "Structural and functional model of intellectual capital at the micro, meso and macrolevels", Russian regions in the focus of change: a collection of reports of the XII International Conference. November 16-18, Ural Federal University named after the first President of Russia B.N. Yeltsin, 2017, pp. 31-46.

[2] N.Sh. Khuzina, "Structure of intellectual capital of the region", Intelligence. Innovations. Investment, vol. 5, 2016, p. 52-57.

[3] J. Roos, "Intellectual capital. Management practice", High school of management, 2010, p. 456.

[4] J.D. Zeghal, A. Maaloul, "Analysis of value added as an indicator of intellectual capital and its implications for company performance", Journal of Intellectual Capital, vol. 11(1), 2010, pp. 39-60.

[5] M.A. Oskolkova, Intellectual capital as a factor of investment attractiveness of companies, Dis.... Cand. Econ. Sciences, 2013, pp. 187.

[6] K.E. Sveiby, "A knowledge-based firm theory for guidance in strategy formulation", Journal of intellectual capital, vol. 2(4), 2011, pp. 344 358

[7] D.A. Corpakis, "European regional path to the knowledge economy: challenges and opportunities, Intellectual capital for communities", Countries, regions and cities, USA, 2011, pp. 213-226. 
at the 6th European Conference of Knowledge Management (ECKM), University of Limerick, Limerick, 2005.

[17] E. Pasher, S. Shachar, "The intellectual capital of state of Israel", Intellectual Capital for Communities. Nations, Regions and Cities, Elsevier Butterworth-Heinemann, Burlington, 2005, pp. 139-150.

[18] D. Weziak, "Measurement of national intellectual capital: application to EU countries", IRISS Working Paper Series vol.13, 2007.

[19] D.I. Mashkina, "Modern model of intellectual capital market", Intelligence. Innovations. Investment, vol. 6, 2016, pp. 42-47.

[20] M. Rosinska-Bukowska, "Human Capital and Intellectual Capital in Modern International Business - Based on Studies of the Strategies of Transnational Corporations', Comparative Economic Research. Central and Eastern Europe, vol. 22, 2019, pp. 141-158.

[21] M. Markhaichuk, I. Zhuckovskaya, "The spread of the regional intellectual capital: the case of the Russian Federation", Oeconomia Copernicana, vol. 10, 2019, pp. 89-111.

[22] D.I. Mashkina, "Types of intellectual capital market", Beginning in science: a collection of reports of the V International scientific and practical conference of schoolchildren, students, undergraduates and postgraduates dedicated to the 30th anniversary Of the Institute of Economics, Finance and business of BSU, April 26, Ufa, 2018, pp. 236 239.

[23] N.A. Kuzminykh, D.I. Mashkina, N.Sh. Roze, "Assessment of the efficiency of the intellectual capital market", The European Proceedings of Social \& Behavioural Sciences EpSBS, vol. LVIII(85), 2018, pp. $751-757$. 